\title{
The Holodomor and Soviet State Terrorism
}

\author{
C. McGrath \\ Public Administration Department, Specialty: Political Science, Taras Shevchenko National University of Kyiv, (Kyiv, Ukraine) \\ (San Diego, California, United States) \\ Corresponding author. E-mail: charlesm365@gmail.com, https://orcid.org/0000-0003-1082-6466
}

Paper received 16.04.19; Accepted for publication 15.05.19.

https://doi.org/10.31174/SEND-HS2019-199VII33-18

\begin{abstract}
How did Stalin kill millions of Ukraine's peasant class and intellectual elite and how has it affected the present Ukrainian national identity? This paper tells the story of a deliberate man-made famine and terror campaign carried out by Stalin and his Bolshevik government.
\end{abstract}

Keywords: Ukraine, Political Science, History, Master Narrative, Russia, Holodomor, Purges, Stalin.

Purpose: The purpose of the article is to help the reader understand the traumatic events known as the Holodomor and Great Purges - atrocities committed under Moscow rule that are part of Ukrainian national identity.

Methodology: My methodology draws on many sources discussed in my previous paper, Master Narratives of Ukrainian Political Culture. Some of the sources were Carl Yung and Joseph Campbell who greatly contributed to our understanding of archetypes, story form, and how they affect the audience. Campbell's analysis on the Hero's Journey myth was very helpful in understanding the hero story form and its significance. Moreover, $\mathrm{H}$. Porter Abbott, Gerald Prince, and Edward Forster have excellent works on story and narrative structure. Predominantly I draw from research done by Jeffry Halverson, H.L. Goodall, and Steven Corman, in Master Narratives of Islamic Extremism for deconstructing narratives.

Findings: The narratives of the Holodomor and Great Purges, aka Great Terror, follow a victimization story line with victim, tyrant and imperialist archetypes. These stories support Ukraine's Imperial Oppressor Master Narrative that is repeated throughout its history.

Originality: The focus on telling the stories from the Ukrainian perspective(s) and understanding the elements of the victimization story form and the archetypes at play adds a unique approach to understanding the complex history shaping Ukrainian identity and fueling the current conflict between Russia and Ukraine.

Practical Value: Understanding the main points of the stories from the Ukrainian perspective(s), and how they support Ukrainian national identity will help US policy makers in spotting and understanding the Russian counter narratives and how they are used to influence Russian, Ukrainian and Western audiences.

Analysis of the recent achievements: Various sources are used for historiography of Ukrainian history concerning the Holodomor and Great Purges including notable historians Timothy Snyder, Serhy Yekelchyk, Orest Subtelny, Serhii Plokhy, Anne Applebaum, Anna Reid, and Nicolas Werth, Simon Sebag Montefiore, Gerard Chaliand, Arnald Blin, and quotes from contemporary Ukrainian leaders.

Introduction: Among the Ukrainian events during Soviet rule, few are as traumatic as the Holodomor and Great Purges in the 1930s. These stories are deeply embedded and retold by Ukrainians today - young and old. Having a moral force, the stories establishes a clear distinction between good and evil. In order to understand how and why these atrocities occurred, we need to begin in the aftermath of World War I, Stalin's rise to absolute power, and the forced collectivization and subordination of the Ukrainian people from the late 1920's to late 1930's. This paper will conclude with an analysis on how the two events are structured as a system of stories supporting the transhistorical imperial oppressor master narrative.

\section{It is far safer to be feared than loved-Machiavelli} Chapter XVII

Following World War I and Ukraine's failed bid for nationhood during the Ukrainian War of Independence 1917-1921, the Soviet Union took most of Ukraine with Poland taking Galicia and the greater part of Volhynya per the Treaty of Riga in 1921. The Bolshevik's had succeeded, and Ukraine was once again ruled by Russia. After decades of Tsarist Russia's attempt to rid Ukrainian's of their language, the Bolsheviks changed tactics. Lenin, considering the importance of winning the hearts and minds in Ukraine, began a program known as Ukrainization in 1923 - which would be reversed in 1933 under Stalin. Also, the Bolshevik's emphasized education, a move which was in contrast to Tsarist polices. Thus, ten years after Red October the country's literacy rate among urbanites had risen from $40 \%$ to $70 \%$ [1]. Despite the achievements of the Bolshevik policies, it was not without growing resistance among Ukrainians who still hoped for independence - especially in the Galician and Volhynian regions of Northwest Ukraine.

Lenin laid the foundation for consolidating power and controlling the masses. He understood the effectiveness of mass terror and thus, on December 7, 1917 created the Soviet secret police named Cheka, precursor to the NKVD and KGB. The Bolshevik's believed they had to eradicate the old system and everyone that supported it, starting with the Tsar and his family. Not to be expelled from the country, or imprisoned - they were executed Tsar Nicholas, his wife Alexandra, their five children, and all the servants. Next, in order to put down rebellions, and there were many, Lenin instructed the Cheka to conduct massive arrests which included hostage taking of the bourgeoisie, i.e., he had the wealthiest people of the important grain producing districts taken hostage, and if the districts didn't comply with his requisition plan, the hostages were executed. Lenin also built concentration camps which Stalin later expanded. Lenin's execution of the Red Terror between $1917-1921$ cost the lives of 500,000 to 2 
million people in the Soviet Union. A campaign meant to destabilize the population while stabilizing the regime [2].

In 1927 Stalin, gained control of the Bolshevik party. Unlike Lenin, Stalin's strategy was to speed up industrialization at all costs. Like Lenin, he was determined to break any resistance. Stalin took advantage of Lenin's creation of institutionalized terror to strengthen his hold on power, and continue eradicating people he believed posed a threat to the regime. One of the biggest targets of the new regime would be the peasants. As Nikita Krushchev said, "For Stalin, peasants were scum." (Subtelny, 2009, p. 404) [1] For the Bolsheviks, they represented 'petty bourgeois', and these peasants or "small independent producers" support the bourgeois, i.e., the owners of production and employers to the wage earners [3]. In adhering to Marxist doctrine, the Bolshevik's believed both classes had to be destroyed.

In 1928 Stalin implemented his first Five-Year Plan having ousted the more moderate Nikolai Bukharin. Bukharin had been a high ranking and loyal Bolshevik. Yet, he disagreed with Stalin's plan for forced collectivization. Stalin would later have Bukharin executed for disloyalty during the Great Purge of 1936 - 1938 [4]. In practice, collectivization meant that the people who owned farms became state employees of the Soviet Union and their farms then belonged to the state. During the 1920s the Bolshevik's had begun their communistic policies of nationalizing estates and industries and confiscating grain from peasants, then setting unreasonably high quotas. The Bolshevik's also limited the amount of grain peasants were allowed to keep to as little as thirty pounds per month [1]. Penalties were strict; in 1932 a policy was implemented stating that any man, woman, or child taking even a handful of grain from a collective farm could be executed [1]. The Russian writer Mikhail Sholokhov reported the following account on peasants who had been suspected of hiding grain. The following two methods were used during the interrogations.

The "cold" method: the worker is stripped bare and left out in the cold, stark naked in a hangar. Sometimes whole brigades of collective workers are treated in this fashion.

The "hot" method: the feet and the bottom of the skirt of female workers are doused with gasoline and then set alight. The flames are put out, and the process is repeated ... [4]

Stalin was intent on surpassing the west in the Soviet Union's industrial development. At the First Conference of Workers in 1931 Stalin said, "We are fifty or a hundred years behind the advanced countries. We must make up this gap in ten years. Either we do it or they will crush us." [5] Being inspired to propel your country forward is one thing, being willing to sacrifice the lives of ones' people, another. Yekelchyk states that, "The Soviet state was determined to extract from the republic the maximum amount of grain for sale abroad, in order to fund the Kremlin's mammoth industrial projects." [6]. To achieve his goal, Stalin sped up the process of collectivization. The plan involved buying grain from peasant landowners known as 'kulaks' well below the market value, as low as one-eighth the market price [1]. When the kulaks refused the low-price, Stalin decided it was time to destroy them as a class known as 'dekulakization'. Soviet propaganda portrayed the program as class warfare - "a crusade against the rich peasants or kulaks" [3]. Yet, on average the peasant income was half of what the average industrial worker earned; the industrial worker being the ideological support base for the Soviets.

In the early 1930's, as part of the dekulakization program, more than a million Ukrainian families were forced onto trains, and deported to Siberia. The train rides covered multiple time zones over thousands of miles. Many Ukrainians, especially children died from the cold before reaching their destination $[7 ; 8$; 9]. In Ukraine, as in Kazakhstan, many peasants protested collectivization by hiding grain and slaughtering their animals. On a more limited scale peasants revolted violently. Yekelchyk cites one such revolt by peasants in Chernihiv province, which was joined by soldiers of the $21^{\text {st }}$ Red Army Regiment. From February 20 to April 2, 1930, 46 Soviet officials were killed and 84 wounded [3]. Still, given their hopeless situation many peasants began to cede to Moscow and allow their farms to be collectivized.

Stalin reacted to the peasant resistance by raising the quotas and confiscating all grain from individual farmers. This started a chain reaction resulting in famine in Ukraine as well as southern Russia and Kazakhstan. People began to starve in 1931 in Ukraine, Kazakhstan, and southern Russia, with the famine reaching its height in 1932. Yet, in 1932 Stalin chose to raise the grain quota by 44 percent. By June 1932, more than 80,000 people had starved in the Kyiv region. Upon receiving a letter reporting the situation and asking for help, Stalin denied that there was a famine and "banned the word itself from official correspondence." [10] Ever the pragmatist, he ordered filmmakers to make films not to show how things were, but how they should be - making films of peasants in radiant fields [11].

During the famine, Ukrainians attempted to leave their villages in search of food but were prohibited to do so. Early in 1933, armed guards were posted at the Ukrainian Russian border to prevent starving Ukrainians from crossing into Russia in search for food [6]. The West sent trains full of grain to the Soviet Union in response to the famine, but Stalin refused to accept the much needed food [12]. In fact, while his people were starving in Ukraine, Kazakhstan and Kuban Russia, all places that had previously protested collectivization, Stalin continued to export grain [4]. In Stalin's eyes the famine was a result of the resistance to policies necessary to force progress. The following quote, details his 'ends justifies the means' approach to the collectivization program,

"A ruthless struggle is going on between the peasantry and our regime. It's a struggle to the death. This year was a test of our strength and their endurance. It took a famine to show them who is master here. It has cost millions of lives, but the collective farm system is here to stay. We have won the war!" [1]

Sadly, between three to six million Ukrainians died during the famine and it remains one of the strongest atrocity narratives among the Ukrainian people as a result of Soviet rule [13].

\section{The Great Terror}

... and those whom he offends, remaining poor and scattered, are never able to injure him; whilst the rest being uninjured are easily kept quiet, and at the same time are anxious not to err for fear it should happen to 
them as it has to those who have been despoiled. - Machiavelli Chapter III

After the Bolshevik's took over, they carried out a number of purges starting in 1919 to strengthen their grip over the Soviet Union. The terror campaign began in 1934 and reached its height in 1937. Of all the republics, Stalin considered Ukraine the greatest threat to Moscow rule given the size of its population, more than 29 million in 1926 [10], and fact that the majority were peasants with bourgeois and nationalistic tendencies. According to Plokhy, Stalin had never gotten over the surprise attack on Bolshevik forces in 1920 by the Polish and Ukrainian armies under Jozef Pilsudski and Simon Petliura, which had driven the Red Army out of Kyiv. Thus, in Stalin's mind it was a real possibility that such a rebellion could reoccur, and he was determined to stop it.

During the Great Purge of 1937-1938 Stalin's secret police, called the NKVD and headed by Nikolai Yezhov, arrested Ukrainians of various classes but especially the political elite. Many of whom were communists and had supported the Bolshevik's. After an interrogation and being forced to confess to fabricated crimes they were executed. Even worse, during the interrogations they had to name someone who had recruited them and who they had recruited. Usually, they named friends but some even named family members - sealing them the same fate [1].

It's difficult to measure the psychological impact state terrorism had on Ukrainian society. From the ordinary peasant to the elite - everyone felt the reach of Stalin. People spoke to each other in code afraid to say anything negative about him. The day-to-day atmosphere and control that Stalin exerted in which people feared being arrested can be understood by the following passage:

For these people, this meant unremitting dread. Dread of hearing a knock on the door in the middle of the night; dread of disappearing forever. Collectively, the psychological toll was appalling and impossible to quantify. Insecurity, fear, and unpredictability were the order of the day... The least false step or unguarded word could mean death or the Gulag [2]

Subtelny estimates that 3-12 million people were sent to labor camps, with a high percentage of them being Ukrainian. Moreover, Subtelny calculates around 500,000 people were executed during the purge of 1937-1938, while Snyder's research concludes that " 681,692 people were shot" [1]. Plokhy also reports that nearly 270,000 people were arrested in between 1937-1938 with almost half of them executed. Although the numbers vary, all of the figures are tragically high. Ironically, Yezhov met the same fate as his victims in 1940 when Stalin had him executed, blamed for the excessive number of victims and accused of being a spy [14].

In describing the long term impact on Ukrainian society historian Anne Applebaum writes the famine and purges during the 1930's eliminated the nations' best minds scholars, writers, and political leaders. Stalin's use of state terrorism removed resistance within Ukraine, and the people who were left were "frightened into silence and obedience" ... "the state became something to be feared, not admired" thus, the passivity or perhaps fatalistic outlook present with much of the current Ukrainian population stems from 1933 [15]. With so much time passing since 1933, it seems inconceivable that a minority could get away with such brutality over the majority. Yet, modern history shows us far too many examples: the Chinese communists under Mao Zedong, the Khmer Rouge Regime in Cambodia, Boko Haram in West Africa, ISIS in Iraq and Syria, the Taliban in Afghanistan - perhaps Mao was right when he said, "political power grows out of the barrel of a gun." [16].

The Holodomor and Great Purge of 1937-38 master narratives are often spoken of in the same breath, as they occurred in succession and with the same intention - to consolidate power and break nationalistic aspirations and resistance to Moscow rule. The retelling of the Holodomor and Great Purge follow a victimization story form with Stalin as the archetypal tyrant and Bolshevik ruled Soviet Union as the imperial oppressor, and Ukrainians as the victims - the events serving as a subset of the imperial oppressor master narrative. References to the Holodomor and Great Purge frame contemporary conflicts and events concerning Russia such as The Orange Revolution, Euromaidan Revolution, annexation of Crimea, and Russian backed insurgency in Donbass. The narrative trajectory guides the intended audience to resist the imperialist, i.e., Russia, and to defend and liberate the people of Ukraine. For many Ukrainians including former President Yushchenko, the Holodomor is referred to as a genocide placing Stalin in the same category as Hitler and serving as a reminder of the consequences for failing to resist Moscow rule. During a visit to the UK in 2008 "President Yushchenko opened an exhibition 'Execution by Hunger: the unknown genocide of Ukrainians', dedicated to the 75th anniversary of the Holodomor of 1932-33, in the House of Lords." He said that the action was "focused on destroying a whole nation" and it was the "worst act of genocide in human history, in which almost 10 million people died". Furthermore, he cited the terror aspect of the famine which for decades remained unknown as survivors were afraid to even talk about it, "Those who spoke about the Holodomor risked repression." [17] Even President Kravchuk, who made his career as a Soviet apparatchik, said of the famine, "A democratic form of government protects a people from such misfortunes,"... "If we lose our independence we are destined to forever lag far behind economically, politically and culturally. If this happens, most importantly, we will always face the possibility of repeating those horrible pages in our history, including the famine, which were planned by a foreign power." [15]

On September 20, 2017 President Poroshenko said the following at the UN General Assembly in New York, "It was an man-made famine in Ukraine in 1932-1933, organized by the totalitarian regime of Stalin, which killed 7 to 10 million Ukrainians," [18] Moreover, on November 25, 2017, at a commemoration of the Holodomor President Poroshenko spoke of the famine and purges arguing that the acts were committed to pacify the whole of Ukraine,

"the main motive for organizing the Holodomor was that Ukrainians - the second largest nation of the former Soviet Union - had a huge cultural and historic heritage, their own traditions of state-building, the experience of national liberation struggle"... "the peasants were killed by starvation, and the intellectual class - by bullets" ... 
"They shot the chosen ones, but aimed to exterminate the whole Ukraine." [19]

Following the massive Vostok-2018 Russian military exercises, Ukrainian General Viktor Muzhenko commented that the exercises were clearly an example of "their
[Russia's] actual plans to conduct offensive operations against Ukraine." [20] The current conflict between Russia and Ukraine adds to the fear of an escalation and consequently strengthens the unity of the Ukrainian people and the Imperial Oppressor Master Narrative.

\section{REFERENCES}

1. Subtelny, Orest. Ukraine: A History. Toronto : University of Toronto Press Incorporated , 2009.

2. Chaliand, Gerard and Blin , Arnaud. The History of Terrorism. Berkeley : University of California Press, 2007.

3. Yekelchyk, Serhy. Ukraine: Birth of a Modern Nation. New York : Oxford University Press, 2007.

4. Werth, Nicolas. A State Against Its People: Violence, Repression, and Terror in the Soviet Union. [book auth.] Mark Kramer. The Black Book of Communism. Cambridge, Massachusetts : Harvard University Press , 1999, pp. 33-268.

5. Why did Stalin want to industrialise the USSR?. The National Archives. [Online] February 15, 2019 http://www.nationalarchives.gov.uk/education/heroesvillains/ $\mathrm{g} 4 / \mathrm{cs} 1 /$.

6. Yekelchyk, Serhy. The Conflict of Ukraine: What Everyone Needs to Know. New York : Oxford University Press, 2015.

7. Solzhenitsyn, Aleksandr. The Gulag Archipelago, 1918-1956. New York : Harper \& Row, Publishers, 1974.

8. Conquest, Robert. The Harvest of Sorrow: Soviet Collectivization and the Terror-Famine. New York : Oxford University Press, 1986.

9. Top Soviet denounces Stalin's gulags. Quinn-Judge, Paul. June 16, 1987, The Christian Science Monitor.

10. Plokhy, Serhii. Gates of Europe: A History of Ukraine. New York : Basic Books, 2015.

11. Bulley, Tony. Stalin: Inside the terror. Dir. Bulley, Tony. [perf.] Sian Phillips. British Broadcasting Corporation \& Granada Television, 2003.

12. Dadabayeva, Gulnara. [interv.] Charles McGrath and Nygmet Ibadildin. September 2016.

13. Snyder, Timothy. Bloodlands: Europe Between Hitler and Stalin. New York : Basic Books, 2010.
14. Montefiore, Simon Sebag. Stalin: The Court of the Red Tsar. New York : Vintage Books, 2003.

15. Applebaum, Anne. Red Famine: Stalin's War on Ukraine. New York : Doubleday, 2017.

16. Tse-Tung, Mao. Selected Works of Mao Tse-tung: Vol. II. Peking : Foreign Language Press, 1965.

17. President Yushchenko - Speeches on Holodomor. Association of Ukrainians in Great Britain. [Online] 2008. https://www.augb.co.uk/president-yushchenko-speeches.php.

18. Ukraine Remembers Victims of Holodomor (1932-1933). UNIAN. [Online] November 25, 2017. https://www.unian.info/society/2262574-ukraine-remembersvictims-of-holodomor-1932-1933.html.

19. Russian Federation assumed responsibility for the crimes of the Soviet regime - President Poroshenko on the anniversary of the Holodomor in Ukraine. President of Ukraine: Petro Poroshenko Official Website. [Online] November 25, 2017. https://www.president.gov.ua/en/news/rosijska-federaciyavzyala-na-sebe-vidpovidalnist-za-zlochin- 44706.

20. Russia Planning Offensive Operations against Ukraine. UNIAN. [Online] February 26, 2019. https://www.unian.info/war/10461288-russia-planningoffensive-operations-against-ukraine-general-staff-in-kyivsays.html.

21. Reid, Anna. Borderland: A Journey Through the History of Ukraine. New York : Basic Books, 1997.

22. Yushchenko. Ukrainian President Yushchenko Yushchenko's Address before Joint Session of U.S. Congress. Official Website of President of Ukraine. [Online] April 6, 2005. https://web.archive.org/web/20061006021607/http://www.pre sident.gov.ua/en/news/data/print/173.html. 